\title{
Beyond financial success: success goals of creative entrepreneurs
}

\author{
Vladimír Baláž ${ }^{1}$,Tomáš Jeck ${ }^{2^{*}}$ (1) and Miroslav Balog ${ }^{1}$
}

\section{${ }^{*}$ Correspondence:}

tomas.jeck@savba.sk

${ }^{2}$ Institute of Economic

Research, Slovak Academy of Sciences, Šancová 56, 813 64 Bratislava, Slovak Republic Full list of author information is available at the end of the article

\begin{abstract}
This paper presents evidence on the identities, values and success goals of creative entrepreneurs in Slovakia. The research relies on a database of creative firms supported by the Slovak Creative Voucher Scheme. The survey-based research compares the success goals of creative entrepreneurs with those of people from conventional industries. The research design acknowledges substantial regional economic disparities in Slovakia. The success goals of creative entrepreneurs from the Bratislava region are compared with those of entrepreneurs from less developed regions. Non-parametric tests are applied in order to establish between-group differences. We found that creative entrepreneurs indeed had their own sets of business motives and success goals, different from those of entrepreneurs in conventional industries. The success goals of creative entrepreneurs were not impacted by the location of the business. Creative entrepreneurs located in the capital region of Bratislava had the same structure of success goals as that of people from underdeveloped regions.
\end{abstract}

Keywords: Creative industries, Creative entrepreneurs, Lifestyle goals, Success criteria, Creative vouchers

\section{Introduction}

Creative industries constitute an important and rapidly developing sector in many European economies. Economic research points to significant direct and indirect effects of creative industries upon not only economic growth, employment, and foreign trade (Boix-Domènech \& Rausell-Köster, 2018), but also social inclusion and social and cultural development (Daubaraitė \& Startienė, 2015). Creative industries are defined both by the NACE codes and occupations. Eurostat data indicate that cultural and creative industry activities accounted for nearly 3.7\% of EU employment in 2015 (8.4 million jobs in 2015) (Eurostat, 2018). Most employment in creative industries relates to jobs in marketing and sales, advertising, information technology and telecommunications, computer programming and software development, web design, media, as well as visual arts, design, music, and writing (DCMS, 1998).

Many European governments have designed schemes supporting the development of creative industries (Bakhshi et al., 2013; Shiach et al., 2017). This research examined whether creative entrepreneurs account for specific sets of business motives and success goals, different from those found in conventional industries. For enhancing the impacts

(c) The Author(s) 2022. Open Access This article is licensed under a Creative Commons Attribution 4.0 International License, which permits use, sharing, adaptation, distribution and reproduction in any medium or format, as long as you give appropriate credit to the original author(s) and the source, provide a link to the Creative Commons licence, and indicate if changes were made. The images or other third party material in this article are included in the article's Creative Commons licence, unless indicated otherwise in a credit line to the material. If material is not included in the article's Creative Commons licence and your intended use is not permitted by statutory regulation or exceeds the permitted use, you will need to obtain permission directly from the copyright holder. To view a copy of this licence, visit http:// creativecommons.org/licenses/by/4.0/. 
of public support upon creative industries, it is important to understand specific identities and values shared by creative entrepreneurs.

This paper presents evidence on the identities, values and success goals of creative entrepreneurs in Slovakia. The research relies on a database of creative firms supported by the Slovak Creative Voucher Scheme. The research compares the success goals of entrepreneurs from creative industries with those from conventional industries. The research design acknowledges substantial regional economic disparities in Slovakia. The success goals of creative entrepreneurs in the Bratislava region are compared with those of people from less developed regions. The key finding is that creative entrepreneurs indeed have their own sets of business motives and success goals, different from those of entrepreneurs in conventional industries. The success goals of creative entrepreneurs are not impacted by the location of the business.

The remainder of the paper is organised as follows. The next chapter reviews key literature on the identities, values and success goals of creative entrepreneurs. A research gap is identified and the research hypotheses are stated. Chapter three introduces the data sources and research methods. Chapter four presents the results of an online survey with entrepreneurs from creative and conventional industries. Non-parametric tests are used to analyse the results between the two groups of entrepreneurs. The concluding part of the paper summarises the key findings, points to some important limitations, and suggests a direction for further research.

\section{Identities, values and success goals of creative entrepreneurs}

\section{Literature review}

The literature was identified primarily on the basis of searches on Web of Science, Scopus, and Google Scholar pages for various keywords (e.g. "creative industries; creative entrepreneurs" AND "values; success criteria").

Literature on traditional entrepreneurship heavily borrows from the theory of planned behaviour (Ajzen, 1991). The theory assumes that entrepreneurship is an intentional process and subject to goal setting and planning. Individual entrepreneurs, of course, may express specific attitudes and follow their own subjective norms. There are many motives underlying entrepreneurship (Murnieks et al., 2019; Stenholm, 2011; Stephan et al., 2015). The most representative surveys on motives for starting and growing businesses, i.e. the Global Entrepreneurship Monitor (GEM) and the EU Flash Barometer, recognise two basic motive types: opportunity-driven and necessity-driven motives. The former type refers to positive motives such as achievement, challenge and learning, independence and autonomy, income security and financial success, and recognition and status. Meanwhile, the latter type describes negative motives such as the necessity to secure new sources of income after losing one's job. Contemporary literature acknowledges the diversity of motives for entrepreneurship and goal-oriented intentions. Opportunity recognition and firm growth are key goal intentions of traditional entrepreneurs (Gorgievski et al., 2018; Kautonen et al., 2015; Koryak et al., 2015).

Entrepreneurs in creative industries account for some specific goals and behaviours. The entrepreneurial identity of business owners in creative industries is influenced by their cultural and creative identity (Werthes et al., 2018). Some goals go beyond monetary success and include factors such as workplace relationships, personal fulfilment, 
and community impact (Wach et al., 2016). Highly creative entrepreneurs are more likely to recognise market opportunities and feel a sense of career achievement, but the perceived achievement need not necessarily convert into financial satisfaction. Opportunity recognition relates to the desire to increase an entrepreneur's social reputation, capability enhancement, and ability to meet the demands of potential customers (Chang \& Chen, 2020, p. 759). Some creative entrepreneurs seek work-life equilibrium and a need for social reputation and are happy to cover basic financial needs (Chen et al., 2017, p. 1). Research on small business owners (Georgievski et al., 2011) pointed to success criteria alternative to monetary success, such as personal satisfaction, the satisfaction of clients and employees, a work-life balance, public recognition, and contributing back to society.

Creative industries are associated with metropolitan and/or highly urbanised regions (Boix-Domènech et al., 2016). On the supply side, metropolitan regions provide creative firms with a rich cultural heritage and abundant 'creative class' (Florida, 2005; Lazzeretti et al., 2012). The creative class includes specific occupations such as scientists, engineers, architects, artists, computer programmers, designers, etc. (Florida, 2002). On the demand side, meanwhile, metropolitan regions provide creative entrepreneurs with plentiful opportunities to sell their products and services. Creative firms, however, are not confined to metropolitan areas only. Some owners of creative businesses prefer bohemian lifestyle values to profit-oriented business goals. The relatively lower income received for their work means that they had to operate in rural regions with lower costs of living (Bennet et al., 2015, p. 2339). A classical study on crafts retailers in nine southeastern US states, for example, pointed to crafts retailers' own definition of success: a 'combination of satisfying goals for achieving personal happiness and fulfilment, gaining independence and control over their lives, and increasing sales and profit, along with more personal goals of expressing their talents and receiving personal gratification from working with crafts' (Paige \& Littrell, 2002, p. 322). Chaston (2008, p. 819) reviewed a sample of 107 small arts and crafts enterprises within the south-western region of the UK and found that the 'majority of firms were interested in a lifestyle based on fulfilling creative aspirations'. Some authors, however, argue that the relatively low priority given to financial success need not necessarily result from the lifestyle goals of creative entrepreneurs. It may simply reflect a lack of managerial skills and expertise (Pfeifer et al., 2017). Establishing a creative firm in many cases is driven by necessity, rather than by a real intention or inclination towards starting a business (Camelo-Ordaz et al., 2012, p. 527).

Arts and crafts creative entrepreneurs, of course, do not represent the whole spectrum of creative industries. Florida's original definition of the creative class involved occupations combining high levels of creativity with skills in high technologies, such as computer programming or architecture. Do these high-skilled occupations also prefer lifestyle goals to financial success?

\section{Research gap and research hypotheses}

There is abundant literature on the goals of owners of creative firms. No research, to the best of the authors' knowledge, has compared the business goals of owners of creative firms with the goals of their counterparts from conventional industries. Moreover, there 
is no research comparing the business goals of owners of creative firms located in less developed regions with those of owners of creative firms located in capital regions.

Two hypotheses were formulated:

H1 Entrepreneurs in creative industries differ in their economic motives from entrepreneurs in traditional industries.

H2 Creative entrepreneurs from the Bratislava region differ in their success goals from entrepreneurs from less developed regions.

\section{Materials and methods}

\section{Data sources}

Our research is based on primary data from a survey on creative firms. The sample of creative firms was collected from participants of the Slovak Creative Voucher Scheme. The Slovak Government launched the scheme in 2018 with the goal to increase the competitiveness of both SMEs benefitting from creative inputs, and the SMEs in creative industries. Creative enterprises in four broadly defined industries were eligible for the support: (1) architecture, (2) design, (3) advertising and marketing, and (4) software and ICT services. The scheme supported networking for SMEs in creative industries with enterprises in conventional industries via the distribution of creative vouchers. The typical value of a voucher was $€ 5,000$ ( $€ 10,000$ for architecture services). The Slovak Innovation and Energy Agency (SIEA) administered the scheme. The SIEA managed a matching portal for enterprises from creative and conventional industries. Firms from conventional industries applied for a voucher and exchanged it for goods and services provided by creative firms. Some 426 vouchers with a total value of $€ 2.084 \mathrm{~m}$ were distributed in the period 2018-2020.

The Slovak Republic accounts for significant regional disparities. The per capita gross domestic product (in purchasing power parity, GDP in PPP) stood at 162\% of the EU-27 average in the Bratislava NUTS 3 region, but 45\% in the Prešov region in 2018 (Eurostat, 2021). We hypothesise that the success goals perceived by creative entrepreneurs in underdeveloped regions may differ from those of entrepreneurs from developed regions (Bennett et al., 2015; Chaston, 2008; Paige \& Littrell, 2002). The Creative Voucher Scheme had a distinctive regional dimension. Creative firms from the capital region of Bratislava received $46.7 \%$ and firms from the city of Bratislava $42.9 \%$ of the total support. Underdeveloped regions in the south and east of Slovakia received much lower support. Some 21 out of a total of 79 Slovak districts (LAU level 1) received no support under the Creative Voucher Scheme. The distribution of support by 79 Slovak districts is provided in Fig. 1.

\section{Research methods}

We approached the Slovak Ministry of Economy (parent body of the SIEA) to obtain contacts within the enterprises supported by the Creative Voucher Scheme. The ministry agreed to arrange a short web-based survey. It provided a list of supported enterprises as well as their contact details (names, locations and email addresses), under the 


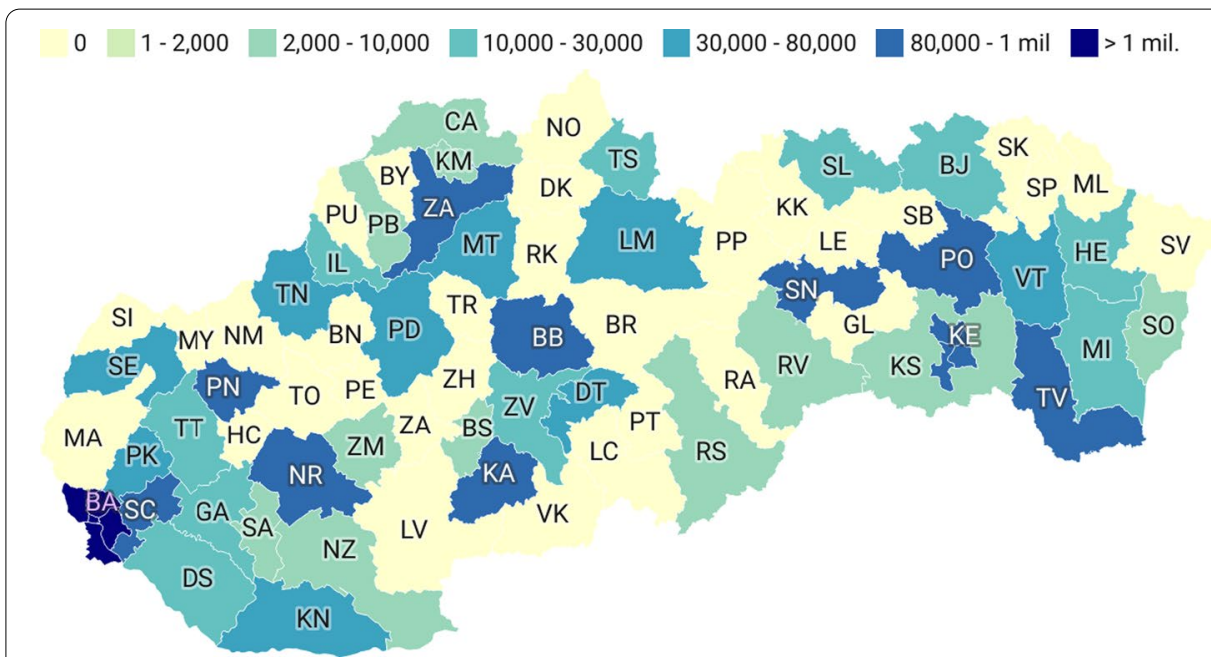

Fig. 1 Support via creative vouchers to creative firms by district (EUR). A complete list of Slovak districts, their official codes, as well as information on areas and populations can be found at: http://www.statoids.com/ysk. html

Table 1 Motives for participation and perceived impacts of the scheme

\begin{tabular}{|c|c|c|c|c|c|c|}
\hline \multirow[t]{2}{*}{ Firm type } & \multicolumn{2}{|c|}{ Conventional } & \multicolumn{2}{|c|}{ Creative } & \multicolumn{2}{|c|}{ Mann-Whitney $U$} \\
\hline & Mean & Std. dev & Mean & Std. dev & U statistics & Sig.* \\
\hline \multicolumn{7}{|c|}{ Please rate key motives for your participation in the scheme } \\
\hline Meeting demands by customers and suppliers & 3.98 & 1.17 & 3.48 & 1.27 & 2061.000 & 0.014 \\
\hline Taking new business opportunities & 4.37 & 0.94 & 3.75 & 1.16 & 1816.000 & 0.000 \\
\hline Improving economic performance & 4.47 & 0.81 & 3.73 & 1.17 & 1624.500 & 0.000 \\
\hline \multicolumn{7}{|c|}{ Please rate perceived impacts of the scheme on your firm } \\
\hline Meeting demands by customers and suppliers & 4.07 & 0.99 & 3.41 & 1.24 & 1883.000 & 0.002 \\
\hline Taking new business opportunities & 4.01 & 0.94 & 3.11 & 1.20 & 1553.000 & 0.000 \\
\hline Improving economic performance & 3.85 & 0.91 & 3.30 & 1.09 & 1996.000 & 0.007 \\
\hline
\end{tabular}

Conventional firms $N=123$; creative firms $N=44$. *Asymp. Sig. (2-tailed)

Please indicate the level of agreement with each statement on a scale: $1=$ strongly disagree and $5=$ strongly agree

condition that the survey addresses the motives for participation and the perceived impacts of the scheme by both creative and conventional enterprises. As for the creative firms, the questionnaire was expanded to include items on monetary and non-monetary success goals. We modelled these items on work undertaken by Paige and Littrell (2002, p. 321). Individual research items were coded using a Likert scale. The participants were presented with the following task: 'Please indicate the level of agreement with each statement on a scale: $1=$ strongly disagree and $5=$ strongly agree.' Specific items and their mean values and standard deviations are presented in Tables 1 and 2.

\section{Results and discussion}

The participant survey was performed in June 2021. We sampled firms from both creative and conventional industries in the survey. The sample of creative firms targeted enterprises from both the Bratislava and non-Bratislava regions. Some 237 
Table 2 Perceived success in specific goals

\begin{tabular}{|c|c|c|c|c|c|c|c|c|}
\hline \multirow[b]{3}{*}{$\begin{array}{l}\text { Achieving personal happiness and } \\
\text { fulfilment }\end{array}$} & \multirow{3}{*}{$\begin{array}{l}\text { Mean } \\
\text { Total } \\
4.18\end{array}$} & \multirow{3}{*}{$\begin{array}{l}\text { Std. dev } \\
\\
0.84\end{array}$} & \multirow{2}{*}{\multicolumn{2}{|c|}{$\begin{array}{l}\text { Mean Std. dev } \\
\begin{array}{l}\text { Non-Bratislava } \\
\text { regions }\end{array}\end{array}$}} & \multirow{2}{*}{\multicolumn{2}{|c|}{$\begin{array}{l}\text { Mean Std. dev } \\
\begin{array}{l}\text { Bratislava } \\
\text { region }\end{array}\end{array}$}} & \multicolumn{2}{|c|}{$\begin{array}{l}\text { Mann- } \\
\text { Whitney U } \\
\text { test }\end{array}$} \\
\hline & & & & & & & \multirow{2}{*}{$\begin{array}{l}U \\
203.00\end{array}$} & \multirow{2}{*}{$\begin{array}{c}\text { Sig.* } \\
0.575\end{array}$} \\
\hline & & & 4.11 & 0.92 & 4.31 & 0.70 & & \\
\hline $\begin{array}{l}\text { Having independence and control over } \\
\text { my life }\end{array}$ & 4.36 & 0.65 & 4.32 & 0.72 & 4.44 & 0.51 & 213.00 & 0.761 \\
\hline $\begin{array}{l}\text { Feeling satisfied with owning my own } \\
\text { business }\end{array}$ & 4.07 & 0.85 & 4.07 & 0.90 & 4.06 & 0.77 & 215.00 & 0.814 \\
\hline $\begin{array}{l}\text { Balancing family/personal life with } \\
\text { work }\end{array}$ & 3.66 & 1.20 & 3.61 & 1.23 & 3.75 & 1.18 & 209.50 & 0.714 \\
\hline $\begin{array}{l}\text { Providing a differentiated product or } \\
\text { service }\end{array}$ & 4.11 & 0.99 & 4.04 & 1.10 & 4.25 & 0.77 & 210.00 & 0.715 \\
\hline $\begin{array}{l}\text { Achieving sales growth or increased } \\
\text { profit }\end{array}$ & 4.02 & 0.85 & 3.96 & 0.79 & 4.13 & 0.96 & 188.00 & 0.340 \\
\hline $\begin{array}{l}\text { Reinforcing the region's cultural } \\
\text { identity }\end{array}$ & 3.52 & 1.30 & 3.36 & 1.39 & 3.81 & 1.11 & 185.50 & 0.334 \\
\hline $\begin{array}{l}\text { Preserving and elevating cultural } \\
\text { heritage }\end{array}$ & 3.11 & 1.28 & 3.07 & 1.36 & 3.19 & 1.17 & 212.00 & 0.763 \\
\hline $\begin{array}{l}\text { Gaining a positive reputation in the } \\
\text { community and with consumers }\end{array}$ & 3.45 & 1.21 & 3.50 & 1.29 & 3.38 & 1.09 & 201.00 & 0.562 \\
\hline $\begin{array}{l}\text { Receiving personal gratification from } \\
\text { creative work }\end{array}$ & 4.36 & 0.75 & 4.25 & 0.84 & 4.56 & 0.51 & 184.50 & 0.286 \\
\hline Expressing my skills or talents & 4.36 & 0.69 & 4.32 & 0.77 & 4.44 & 0.51 & 216.50 & 0.838 \\
\hline
\end{tabular}

creative and 424 conventional firms were addressed, with some 44 and 124 questionnaires being received, respectively. The response rate was that of $18.6 \%$ and $29.2 \%$, respectively. 18 (40.1\%) creative entrepreneurs came from the Bratislava region and 26 (59.9\%) from the non-Bratislava regions.

The participants self-identified their occupations and positions within their firm. The sample of creative enterprises was dominated by specialists in marketing, advertisement, and computer programming (22.7\%), advertisement and marketing professionals $(15.9 \%)$, computer programmers (18.2\%), designers (6.8\%), architects (13.6\%), and other professionals. The survey generated the following results: $65.9 \%$ of participants from creative firms have self-identified themselves as owners/mangers, $25.0 \%$ as owners only, $4.5 \%$ only as managers, and $4.5 \%$ as employees. In the sample of conventional firms, $14.5 \%$ of participants were represented by firm managers, $13.7 \%$ by owners, $57.3 \%$ by owners/managers, and $14.5 \%$ by employees.

\section{Motives for participation in support scheme}

As for the motives to participate in the support scheme, 'improving economic performance' and 'taking new business opportunities' received the highest scores and motives 'related to meeting demands by customers and suppliers' received the lowest 
ones by creative and conventional firms (Table 1). Mean scores assigned by the creative firms to all items were substantially lower than those by conventional firms.

Our dependent variable was ordinal (on a Likert scale). We applied the Mann-Whitney $U$

test in order to compare differences between the creative and conventional firm owners/managers. The $U$ test is a non-parametric alternative to the $\mathrm{t}$-test when the dependent variable is ordinal and not normally distributed. The test was highly significant for all three items. Hypothesis 1 was confirmed: the creative entrepreneurs ranked economic motives for participation in the Creative Voucher Scheme differently from those coming from conventional industries. As for the perceived impacts of the scheme, 'meeting demands by customers and suppliers' received the highest scores and 'taking new business opportunities' and 'improving economic performance' were considered to be less important by both groups. Again, the economic impacts of the scheme received lower scores by creative than by conventional firms. The $U$ test for the difference in scores was significant for all three items (Table 1).

Improved economic performance clearly was the major motive for participation by conventional firms. The creative firms, of course, had to overtake some motives and objectives of the conventional entrepreneurs, as the receive support from the scheme. Creative firms, however, valued lifestyle goals more than economic ones (Table 2). The creative firms conducted their business in volatile and highly unpredictable environments. The Creative Voucher Scheme provided creative firms with opportunities for networking and increases in sales and profits. The economic impacts of the scheme, nevertheless, seemed to be only medium-high for owners/managers of creative firms.

\section{Lifestyle values and success goals}

The medium-high only importance of economic variables may originate in specific lifestyle values and success goals of creative entrepreneurs. The analysis of success goals gives some credit to this assumption (Table 2). Items related to independence and control over one's life, personal expression (gratification from creative work and the ability to express skills and talents), and feelings of personal happiness and fulfilment received (by far) the highest rankings, followed by satisfaction with owning a business, and then achieving sales growth or increased profit. These findings resonate with those by Cnossen et al., (2019, p. 396) on creative entrepreneurs' need for autonomy and freedom, as well as their lower expectations of financial rewards and recognition. Need for life-career balance (Chen et al., 2017), passion and enjoyment from creative work (Bhansing et al., 2018), and desire to express one's creativity through products and services (Patten (2016, p. 23) seem key drivers of creative entrepreneurship.

The $U$ test established for all items that there was no difference between creative entrepreneurs from the Bratislava and non-Bratislava regions (Table 2). Hypothesis 2 was rejected. Perceived success in goals was not impacted by the level of economic development in the region of a firm's residence. 


\section{Discussion}

The key findings of our research refer to the confirmation of Hypothesis 1 and the rejection of Hypothesis 2. Entrepreneurs from creative industries attached lower ranks to economic motives for participation in the Creative Voucher Scheme in comparison to entrepreneurs from conventional industries. The survey on perceived success in specific goals confirmed that lifestyle values (such as 'having independence and control over my life', 'receiving personal gratification from creative work', and 'expressing my skills or talents') scored higher than values measuring economic and financial success ('achieving sales growth or increased profit' and 'feeling satisfied with owning my own business'). The latter two values, however, received quite high rankings.

These results somewhat differ from those by Paige and Littrell (2002) and Chaston (2008). Members of our sample also attached quite low scores to values associated with 'positive reputation with the community and consumers' and 'reinforcing the region's cultural identity'. The differences in value rankings are explained by differences in occupational structure. Paige and Littrell (2002), Bennet et al. (2015) and Chaston (2008) sampled artists and craftsmen, many of whom followed alternative bohemian lifestyles in remote regions and lived 'hand to mouth'. Members of our sample comprised computer programmers, designers, architects, and marketing and advertisement specialists. Entrepreneurs in these occupations were less likely to opt for bohemian lifestyles and more likely to conduct regular business. What is more, computer programmers, designers and marketing specialists were less interested in regional cultural identity and cultural heritage. The finding points to the need for evaluating creative entrepreneurs by their specific occupations, rather than lumping them together.

The structure of occupations may also explain insignificant differences between perceived success in specific goals by entrepreneurs from the Bratislava and non-Bratislava regions. In their hearts, all creative entrepreneurs were real creatives, as indicated by the high scores attached to goals regarding skills, talents, personal gratification, and personal happiness and fulfilment. These values seemed to be independent from the region of business.

\section{Conclusions and direction for further research}

The research had some notable limitations. The sample sizes for creative and conventional firms were rather small. We do not claim that the samples were representative of their respective sectors. The sample sizes did not allow for employing some more sophisticated analytical methods, such as regression and factor analysis. The number of research items in the questionnaire was limited by the agreement with the Ministry of Economy.

Future research may benefit from larger sample sizes and the application of mixed research methods. In-depth interviews, for example, may provide more detailed insights into the antecedents of entrepreneurial motives in creative industries. Interesting questions include (i) how much the success goals are determined by the opportunity versus necessity-driven motives for conducting business in creative industries, and (ii) how much these goals are compatible with performance-oriented programmes of business advice. Chaston (2008, p. 828) suggested that policy interventions aimed at enhancing 
the commercial or entrepreneurial skills of managers of small creative firms may have limited success, as these managers are more interested in sustaining their lifestyle than being financially successful. The assumption may hold for artists and craftsmen, but less so for some other occupations such as computer programmers, advertising and marketing professionals, and architects. We assume that a more detailed knowledge of entrepreneurial motives by specific creative occupations may improve the effectiveness of policies aimed at supporting creative industries.

\section{Abbreviations}

DCMS: Department for Culture, Media and Sport; EU: European Union; GDP: Gross national product; GEM: Global Entrepreneurship Monitor; LAU: Local area unit; NACE: Statistical classification of economic activities; NUTS: Nomenclature of territorial units for statistics; PPP: Purchasing Power Parity; SIEA: The Slovak Innovation and Energy Agency; Sig.: Significance; SMEs: Small and medium-sized enterprises; Std. dev:: Standard deviation; UK: United Kingdom; US: United States.

\section{Acknowledgements}

This research was supported by the Slovak VEGA Grant No. 2/0001/22 and VEGA No. 2/0097/19.

\section{Authors' contributions}

VB was responsible for conceptualisation, methodology, supervision, analysis of survey data, and writing —original draft preparation. TJ: (corresponding author): managed data preparation, cleaning and curation, geographical analysis, and research validation. MB was responsible for project administration, funding acquisition, investigation and survey implementation. All authors read and approved the final manuscript.

\section{Funding}

This research was supported by the Slovak VEGA grant no. 2/0001/22 and VEGA no. 2/0097/19.

\section{Availability of data and materials}

Datasets used and/or analysed during the current study are available from the corresponding author on reasonable request.

\section{Declarations}

\section{Ethics approval and consent to participate}

The authors claim no financial interest or benefit that has arisen from direct applications of the research.

\section{Competing interests}

The authors declare that they have no competing interests.

Author details

${ }^{1}$ Institute for Forecasting, Centre of Social and Psychological Sciences, Slovak Academy of Sciences, Šancová 56, 813 64 Bratislava, Slovak Republic. ${ }^{2}$ Institute of Economic Research, Slovak Academy of Sciences, Šancová 56, 813 64 Bratislava, Slovak Republic.

Received: 11 November 2021 Accepted: 3 February 2022

Published online: 15 February 2022

\section{References}

Ajzen, I. (1991). The theory of planned behavior. Organizational Behavior and Human Decision Processes, 50(2), $179-211$.

Bakhshi, H., Edwards, J., Roper, S., Scully, J., Shaw, D., Morley, L., \& Rathbone, N. (2013). Creative credits—A randomized controlled industrial policy experiment. Nesta.

Bennett, S., McGuire, S., \& Rahman, R. (2015). Living hand to mouth: Why the bohemian lifestyle does not lead to wealth creation in periphery regions? European Planning Studies, 3(12), 2390-2403.

Bhansing, P. V., Hitters, E., \& Wijngaarden, Y. (2018). Passion inspires: Motivations of creative entrepreneurs in creative business centres in the Netherlands. The Journal of Entrepreneurship, 27(1), 1-24.

Boix-Domènech, R., Capone, F., \& De Propis, L. (2016). Comparing creative industries in Europe. European Urban and Regional Studies, 23(4), 935-940.

Boix-Domènech, R., \& Rausell-Köster, P. (2018). The economic impact of the creative industry in the European Union. In V. Santamarina-Campos \& M. Segarra-Oña (Eds.), Drones and the creative industry. Springer.

Camelo-Ordaz, C., Fernández-Alles, M., Ruiz-Navarro, J., \& Sousa-Ginel, E. (2012). The intrapreneur and innovation in creative firms. International Small Business Journal, 30(4), 513-535.

Chang, Y. Y., \& Chen, M. H. (2020). Creative entrepreneurs' creativity, opportunity recognition, and career success: Is resource availability a double-edged sword? European Management Journal, 38(5), 750-762.

Chaston, I. (2008). Small creative industry firms: A development dilemma? Management Decision, 46(6), 819-831. 
Chen, M. H., Chang, Y. Y., Wang, H. Y., \& Chen, M. H. (2017). Understanding creative entrepreneurs' intention to quit: The role of entrepreneurial motivation, creativity, and opportunity. Entrepreneurship Research Journal, 7(3), 1-15.

Cnossen, B., Loots, E., \& Witteloostuijn, A. V. (2019). Individual motivation among entrepreneurs in the creative and cultural industries: A self-determination perspective. Creativity and Innovation Management, 28(7), 389-402.

Daubaraitè, U., \& Startienè, G. (2015). Creative industries impact on national economy in regard to sub-sectors. Procedia: Social and Behavioral Sciences, 213, 129-134.

DCMS. (1998). The creative industries mapping document. DCMS

Eurostat. (2018). Around 8.4 million people employed in culture in the EU. Retrieved from https://ec.europa.eu/eurostat/ web/products-eurostat-news/-/DDN-20180222-1

Eurostat. (2021). Gross domestic product (GDP) at current market prices by NUTS 3 regions [nama_10r_3gdp].

Florida, R. (2002). The rise of the creative class: And how it's transforming work, leisure, community and everyday life. Perseus Book Group.

Florida, R. (2005). Cities and the creative class. Routledge.

Gorgievski, M. J., Ascalon, M. E., \& Stephan, U. (2011). Small business owners'success criteria, a values approach to personal differences. Journal of Small Business Management, 49(2), 207-232.

Gorgievski, M., Stephan, U., Laguna, M., \& Moriano, J. (2018). Predicting entrepreneurial career intentions. Journal of Career Assessment, 26(3), 457-475.

Kautonen, T., van Gelderen, M., \& Fink, M. (2015). Robustness of the theory of planned behavior in predicting entrepreneurial intentions and actions. Entrepreneurship: Theory and Practice, 39(3), 655-674.

Koryak, O., Mole, K., Lockett, A., Hayton, J. C., Ucbasaran, D., \& Hodgkinson, G. P. (2015). Entrepreneurial leadership, capabilities and firm growth. International Small Business Journal: Researching Entrepreneurship, 33(1), 89-105.

Lazzeretti, L., Capone, C., \& Boix-Domènech, R. (2012). Reasons for clustering of creative industries in Italy and Spain. European Planning Studies, 20(8), 1243-1262.

Murnieks, C. Y., Klotz, A. C., \& Shepherd, D. A. (2019). Entrepreneurial motivation: A review of the literature and an agenda for future research. Journal of Organizational Behaviour, Special Issue: THe Job Annual Review and Conceptual Development Issue, 41(2), 115-143.

Paige, R. C., \& Littrell, M. A. (2002). Craft retailers' criteria for success and associated business strategies. Journal of Small Business Management, 40(4), 314-331.

Patten, T. (2016). "Creative?"... "Entrepreneur?"-_ Understanding the creative industries entrepreneur. Artivate, 5(2), 23-42.

Pfeifer, S., Peterka, S. O., \& Stanić, M. (2017). Business models of micro businesses: Empirical evidence from creative industries. Management Science, 22, 1-19.

Shiach, M., \& Virani, T. (2017). Cultural policy, collaboration and knowledge exchange. In M. Shiach \& T. Virani (Eds.), Cultural policy, innovation and the creative economy. Palgrave Macmillan

Stenholm, P. (2011). Innovative behavior as a moderator of growth intentions. Journal of Small Business Management, 49(2), 233-251.

Stephan, U., Hart, M., \& Drews, C. (2015). Understanding motivations for entrepreneurship: A review of recent research evidence (p. 212). Aston University.

Wach, D., Stephan, U., \& Gorgievski, M. (2016). More than money: Developing an integrative multi-factorial measure of entrepreneurial success. International Small Business Journal, 34(8), 1098-1121.

Werthes, D., Mauer, R., \& Brettel, M. (2018). Cultural and creative entrepreneurs: Understanding the role of entrepreneurial identity. International Journal of Entrepreneurial Behavior \& Research, 24(1), 290-314.

\section{Publisher's Note}

Springer Nature remains neutral with regard to jurisdictional claims in published maps and institutional affiliations.

\section{Submit your manuscript to a SpringerOpen ${ }^{\circ}$ journal and benefit from:}

- Convenient online submission

- Rigorous peer review

- Open access: articles freely available online

High visibility within the field

Retaining the copyright to your article

Submit your next manuscript at $\boldsymbol{\nabla}$ springeropen.com 